\title{
Application of Cassava Slicer Machine and Oil Dryer Machine in Micro Enterprises at Simalungun District
}

\author{
Farida Ariani $^{1}$, Tugiman ${ }^{1}$, Eva Sartini Bayu ${ }^{2}$, Ma'ruf Tafsin $^{2}$, Hariadi Susilo $^{3}$, Tulus $^{4}$ \\ ${ }^{I}$ Faculty of Engineering, Universitas Sumatera Utara, Medan \\ ${ }^{2}$ Faculty of Agriculture, Universitas Sumatera Utara, Medan \\ ${ }^{3}$ Faculty of Cultural, Universitas Sumatera Utara, Medan \\ ${ }^{4}$ Faculty of Mathematics and Natural Sciences, Universitas Sumatera Utara, Medan
}

\begin{abstract}
Cassava chip is a type of snack that has attracted public interest and quite promising for the entrepreneurs. So far, sliced cassava and drained cassave chips were produced manually, hence the result are less optimum. Departing from that point of view, this problem become the starting point to provide solutions for the micro-enterprises. The method used in carrying out this training consists of several methods, namely: (1) Survey to the place of partners in the micro business group in Simalungun. (2) Prequestionnaire within this activity is carried out to see how far partners understand how vital the operation and maintenance of the machine. (3) Preparation of cassava slicing machines, this stage consists of several parts including the design of tools that suit the needs of partners, this needs to carry out so that the appropriate equipment specifications obtained. (4) Application of equipment and process analysis, this stage is carried out at the partner's place, this stage demonstrates the use of cassava slicing machines to partners so that the results of a direct analysis are seen to increase the efficiency of the use of machinery to the production process. (5) Counseling to partners, this extension activity is significant to be carried out as part of community service. This extension is done to transfer technology to partners in terms of the use and maintenance of the machines provided; (6) Post questionnaire, the questionnaire activity at the end of the devotion activity aims to measure whether the problem faced by the partner has been resolved, and see the increase in the benefits of the machine being donated.
\end{abstract}

Keywords: cassava slicer machine, cassava chips, oil dryer machine

Abstrak. Keripik singkong merupakan satu di antara jenis camilan yang di minati masyarakat luas. Selama ini mengiris singkong dan meniris kripik singkong di *Corresponding author at: Jalan Prof A. Sofyan No. 3, Kampus USU, Medan 20155

E-mail address: maruf_tafsin@usu.ac.id 
lakukan secara manual. Sehingga hasil yang di peroleh kurang maksimal. Disinilah dibutuhkan penyelesaian masalah dari usaha mikro. Metode yang digunakan dalam melaksanakan pelatihan ini terdiri dari beberapa metode, yaitu: (1) Survei ke tempat mitra di kelompok usaha mikro di Simalungun. (2) Pre kuesioner, kegiatan ini di lakukan untuk melihat sejauh mana mitra memahami bagaimana pentingnya cara pengoperasian dan perawatan mesin; (3) Persiapan mesin pengiris singkong, tahapan ini terdiri dari beberapa bagian diantaranya desain alat yang sesuai kebutuhan mitra, hal ini perlu di laksanakan sehingga di peroleh spesifikasi peralatan yang sesuai; (4) Aplikasi peralatan dan analisa proses, tahapan ini di lakukan di tempat mitra, tahapan ini memperagakan penggunaan mesin pengiris singkong kepada mitra sehingga hasil analisa langsung terlihat peningkatan efesiensi penggunaan mesin terhadap proses produksi; (5) Penyuluhan kepada mitra, kegiatan penyuluhan ini sangat penting di lakukan sebagai bagian dari pengabdian masyarakat. Penyuluhan ini di lakukan untuk mentransfer teknologi kepada mitra dalam hal penggunaan dan perawatan mesin yang di berikan; (6) Post kuesioner, kegiatan kuesioner di akhir kegiatan pengabdian bertujuan untuk mengukur apakah masalah yang di hadapi mitra sudah terselesaikan, serta melihat peningkatan manfaat dari mesin yang di hibahkan.

Kata Kunci: Mesin pengiris singkong, keripik singkong, mesin peniris

Received 20 November 2018 | Revised 16 February 2019| Accepted 14April 2019

\section{Introduction}

Human in their lives always strive to meet their needs in various ways, one of them is by making entrepreneurship. The entrepreneurship can be divided into several types, i.e. Micro, Small, Medium Enterprises (UMKM). Micro-enterprise is the subject of problems in this project. Due in micro-enterprises is still fraught with problems of limitations in terms of improving the quality and quantity of production [1,2]. Then looking at these aspects, taken one example of micro-businesses in the community have done a home-based business producing cassava chips. Due to the result of the cassava chips frying still has a lot of oil and must be drained [3]. The working implementation is conducted manuallly and slow, so we provide solutions to entrepreneurs an appropriate tools called slicer machine and oil dryer machine (spinner).

Cassava chip is a type of snack that has attracted public interest and quite promising for the entrepreneurs $[4,5]$. In order to be able to compete, quality and taste will be the determining factors. If all this time the work is done manually, by using traditional slicer with slow process and there is a lot of frying oil remaining [6]. This is where problem solving is needed. 


\section{Methods}

Based on the things above, there is a solution to overcome the problems faced by partners through literature studies, conducting surveys, providing machinery and training and maintenance of machines to increase productivity in providing quality fried cassava products. In general, solutions can consist of several stages:

1. Survey to partners in farmer groups in Simalungun. This survey is the initial stage of the activity where in this activity aims to see first hand the problems faced. This survey stage is very important to do to get the right solution to the existing problems.

2. Pre Questionaire, this stage was carried out to see how far the partners understood how important the engine operation and maintenance was

3. Preparation, this stage consists of several parts including the design of tools that suit the needs of partners, these to be carried out so that the appropriate equipment specifications are obtained.

4. Equipment applications and process analysis, this stage is done at the partner's place, this stage demonstrates the use of the machinery to the partners so that the results of the direct analysis are seen to increase the efficiency of the use of the machine to the production process.

5. Counseling to partners, this extension activity is very important to do as part of community service. This extension is done to transfer technology to partners in terms of the use and maintenance of the machines that have been provided.

6. Post Questionaire, the questionnaire at the end of the activity aims to measure whether the problem faced by the partner has been resolved, and to see the increase in the benefits of the machine being donated.

7. Scientific journal publications, publication is the final activity of all stages of the activity which will be made in scientific journal and will be published to national scientific journals.

\section{Results and Discussion}

Achievement of Results and outcomes achieved from community service from the university to partners, as the evidenced by the following facts:

1) Efficiency of partner working time in terms of providing production

2) Increasing partner's productivity in serving cassava chips.

3) Increasing insight of the partner community in the presentation of production using machines. 
4) Becoming a motivation for partner communities to turn on business groups in their regions.

5) Partners are able to operate the machine and are able to carry out engine maintenance.

Drive motor

Cassava slicer machine and oil dryer machine (spinner), both use drive motor with specifications power 1 phase $1 / 4 \mathrm{HP}$. This motor serves as the main drive, where the power released by the engine is able to drive the entire main component according to the function of each component. The motor image that is used can be seen in the picture below:

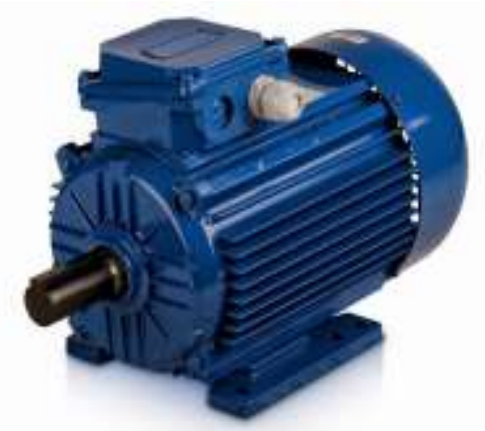

Figure 1. Motor Drive

\section{Bearing}

The bearing is an important part of an engine construction where the bearing will support the axle that is loaded both radially and axially, besides that the bearing will provide a relatively free position to the shaft to rotate. Selection of bearings is based on the size of the shaft used on the machine. The shaft used is a type of ball bearing, this type of bearing has the characteristics of being able to serve high rotation with relatively large loads. The number of pads used is 2 pieces with high quality. Images from the bearing can be seen in the picture below:

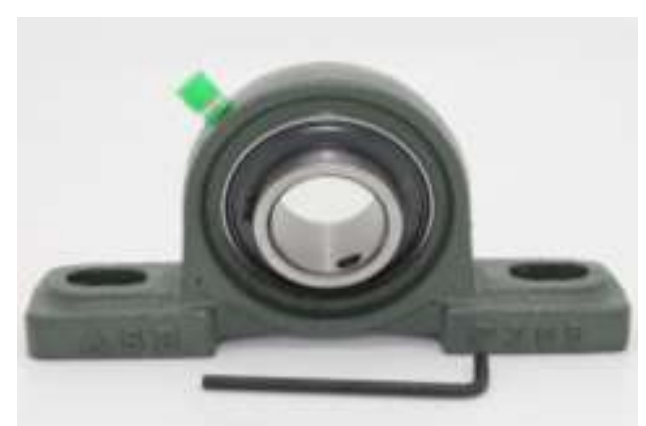

Figure 2. Bearing of cassava slicer machine 


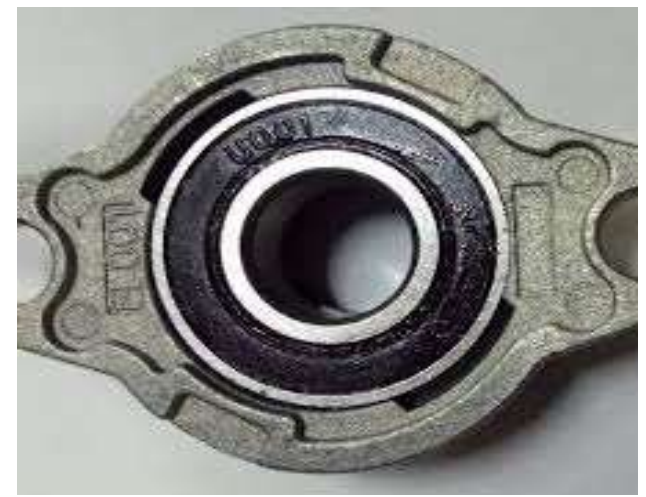

Figure 3. Bearing of spinner

Slicing knife

The slicing knife on this machine is on a stainless plate with diameter of $350 \mathrm{~mm}$ and total of 3 blades made from HSS. Below is a picture of the blade that will be used:

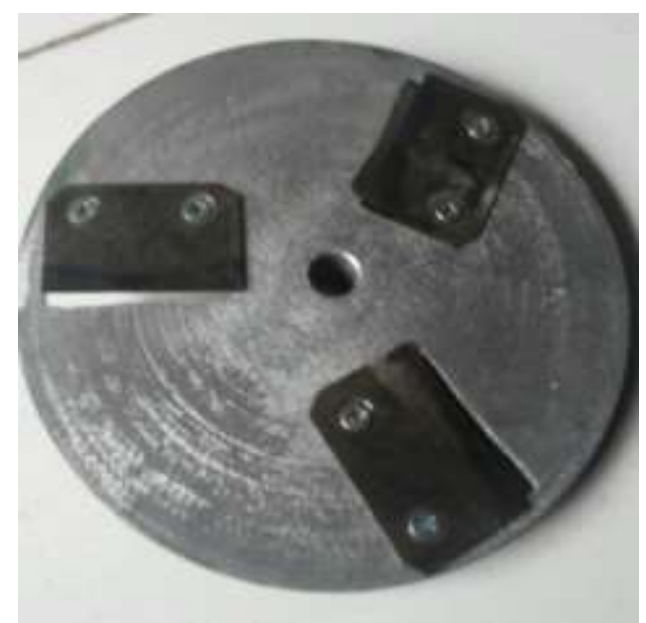

Figure 4. Slicer knife

\section{Dryer filter}

The stainless steel filter driers are $4 \mathrm{~mm}$ in diameter, rotating on the axis of the shaft connected to the dynamo. Below is a picture of the blade that will be used:

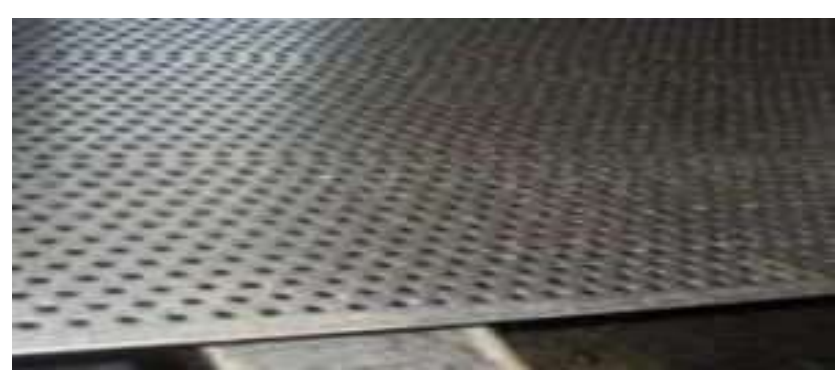

Figure 5. Driver Filter

Spesification of cassava slicer machine

Dimensions $\quad$ : $\quad 650 \mathrm{~mm}$ x $500 \mathrm{~mm} \times 600 \mathrm{~mm}$

Source of energy : Electricity 


$\begin{array}{lcl}\text { Driven by } & : & \text { Electromotor } \\ \text { Electrical voltage } & : & 220 \mathrm{~V}(1 \mathrm{Phase}) . \\ \text { Frequency Electricity } & 50 \mathrm{~Hz} / 60 \mathrm{~Hz} . \\ \text { Power } & : & 1 / 4 \mathrm{HP} . \\ \text { Capacity } & : & 70 \mathrm{Kg}-80 \mathrm{Kg} / \text { process. } \\ \text { Machine Frame } & : & \text { Iron Hollow Bar } \\ \text { Product Material } & : & \text { Stainless Steel. } \\ \text { System } & : & \text { Centrifuge }\end{array}$

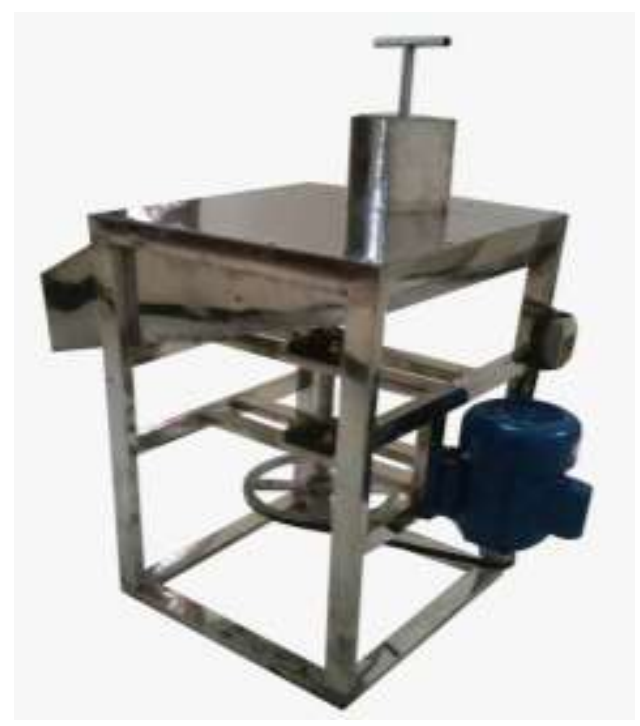

Figure 6. Cassava slicer machine

Function of Cassava Slicer Machine

Cassava Slicer Machine is a tool that has been widely used by culinary entrepreneurs. Among them, there various businesses of fruit chips, cassava chips, snacks, vegetable chips, and other preparations through the process of frying. Therefore, by using a cassava slicer machine the results of the slices are evenly distributed and equally thick so that they are crispy when served.

Spesification of oil dryer machine

Dimensions $\quad$ : $550 \mathrm{~mm}$ x $400 \mathrm{~mm} \times 600 \mathrm{~mm}$

Source of energy : Electricity

Driven by : Electromotor

Electrical voltage : $220 \mathrm{~V}(1$ Phase $)$.

Frequency Electricity: $\quad 50 \mathrm{~Hz} / 60 \mathrm{~Hz}$.

Power : 1/4 HP.

Capacity $\quad: \quad 4 \mathrm{Kg}-5 \mathrm{Kg} /$ process. 
Machine Frame $\quad$ : Iron elbow / Stainless Steel

Product Contact Material : $\quad$ Stainless Steel.

System : Centrifuge

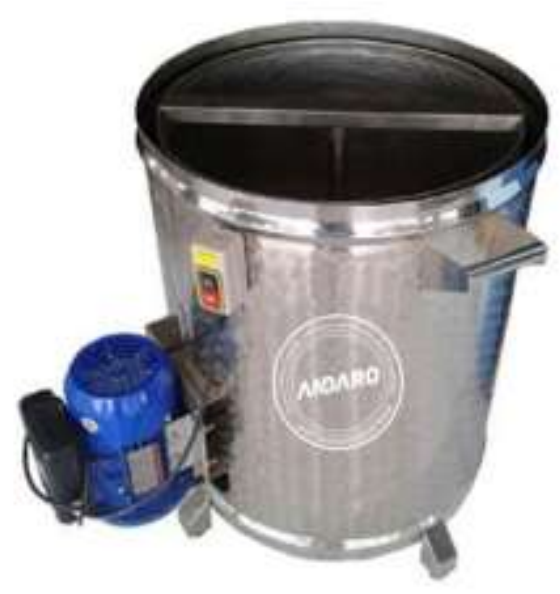

Figure 7. Oil dryer machine

Function of Oil Dryer Machine

The oil dryer machine is a tool or machine that has been widely used by culinary entrepreneurs, Among them are the business of fruit chips, cassava chips, snacks or snacks, vegetable chips, and other preparations through the process of frying. Therefore, by using an oil dryer machine, the frying will less oil and crispy of course.

\section{Conclusions}

The progress of community service activities has reached $90 \%$ of what was planned. Equipment or slicer machine is an effort to improve the mechanism providing quality slices results. Training of equipment operation to partners has been carried out, and installation of the service plank will be carried out. The initial questionnaire has been completed. The next activity is SOP training for the operation and maintenance of production machines will be carried out and the final evaluation of activities will be carried out and reported in the final report of this community service activity.

\section{References}

[1] Subanar H. 2002. Alternative of small industry development/ Craft small industries in a cultural perspective. Prosiding Seminar Prospek Industri Kecil Dalam Perkembangan Perekonomian Indonesia. Surabaya. (In Bahasa Indonesia) 
[2] Budiono B. 2002. Small industries in cultural prespective. Prosiding Seminar Prospek Industri Kecil dalam Perkembangan Perekonomian Indonesia. Surabaya. (in Bahasa Indonesia)

[3] Atmika I K. A., Gatot K. I. M., Suryawan G. P. A. A., Suriadi I G. A. K. 2001. Application of spiral crackers pressing machine to improve the efficiency and capacity of crackers in small industries. Jurnal Pengabdian Kepada Masyarakat "Udayana Mengabdi” 10 (1). (in Bahasa Indonesia)

[4] Badan Penelitian dan Pengembangan Pertanian. 2011. The Benefit of Cassava. Agro Inovasi Sinar Tani. Bogor. (in Bahasa Indonesia)

[5] Machmudi. 2008. Manufacturing of Cassava Chips. Fakultas Teknologi Pertanian Universitas Udayana. Denpasar. (in Bahasa Indonesia)

[6] Nyoto W. 1995. Application of Tapioka Flour Pressing Technology. Lembaga Pengabdian Masyarakat-UNESA. Surabaya. (in Bahasa Indonesia) 